\title{
Evaluation of Gerbera Varieties for Yield and Quality under Protected Environment Conditions in Bihar
}

\author{
Paramveer Singh*, Ajay Bhardwaj, Randhir Kumar and Deepti Singh
}

\author{
Department of Horticulture (Vegetable and Floriculture), Bihar Agricultural University, \\ Sabour-813210, Bhagalpur, Bihar, India \\ *Corresponding author
}

\begin{tabular}{|c|}
\hline Keywords \\
\hline $\begin{array}{l}\text { Gerbera, Polyhouse, } \\
\text { Evaluation, } \\
\text { Varieties, Growth, } \\
\text { Stalk length, } \\
\text { Quality. }\end{array}$ \\
\hline Article Info \\
\hline $\begin{array}{l}\text { Accepted: } \\
\text { 04 July } 2017 \\
\text { Available Online: } \\
\text { 10 September } 2017\end{array}$ \\
\hline
\end{tabular}

\section{Introduction}

Global warming and climate change is the greatest concern of mankind in $21^{\mathrm{st}}$ century. The established commercial varieties of flowers are performing poorly in an unpredictable manner due to irregularity of climate. Commercial production of floricultural plants particularly grown under open field conditions is severely affected by changing climate. Due to high temperature and physiological disorder, crops will be more pronounced. Hence there is a need to protect these valuable crops for sustainability against the climate change scenario. The most effective way is to adopt protected cultivation. To sustain the productivity, modification of present practices and greater use of 
greenhouse technology are some of the solutions to minimize the effect of climate change. Identification of new cultivars of gerbera crop tolerant to high temperature, resistant to pests and diseases and producing good yield under stress conditions, as well as adoption of hi-tech horticulture and judicious management of natural resources will be the main strategies to meet this challenge.

Gerbera is one of the leading cut flowers and ranks among the top ten cut flowers of the world. It has a wide applicability in the floral industry as cut flower and potted plant. It is an important commercial flower grown throughout the world in a wide range of climatic conditions. Its cut blooms remain fresh at least for a week and are in great demand for presentation and interior decoration. The marketing potential can be exploited by introduction and evaluation of gerbera cultivars. There are many excellent varieties of gerbera with magnificent flowers in exhaustive range of colours, different shades, size and wide range of keeping quality. It is very much necessary to evaluate gerbera cultivars under protected conditions.

Hence, present investigation was conducted to study the relative performance of 10 genotypes of gerbera for their growth, flower quality and yield characters under protected conditions at BAU, Sabour.

\section{Material and Methods}

The present investigation was carried out during 2014-2015 at the polyhouse complex, Department of Horticulture (Vegetable and Floriculture), Bihar Agricultural University, Sabour, Bhagalpur, Bihar to evaluate 10 gerbera varieties under naturally ventilated polyhouse conditions (Fig. 1). Experimental material consisted of 10 cultivars of gerbera procured from private company. Ten cultivars viz., Laura, Szantal, Delfin, Newada,
Olympia, Kormoran, Partrizia, Rock, Feliks and Samuraj were selected for this study. Healthy tissue cultured plants were planted at a spacing of $30 \mathrm{~cm} \times 40 \mathrm{~cm}$ in a raised beds of $30 \mathrm{~cm}$ height. The experiment was laid out in randomized block design with three replications. Five plants from each replication of a cultivar were used for recording observation. The recommended package of practices was followed for raising the successful crop. Observations on different parameters of vegetative growth, floral quality and yield parameters were recorded. The mean values of the recorded data on various biometrical parameters were subjected to statistical analysis as per the procedure given by Panse and Sukhatme (1984) and tabulated in tables 1 and 2.

\section{Results and Discussion}

The findings of the present investigation are presented in tables 1 and 2. There was significant difference among the different varieties of gerbera regarding vegetative growth, floral quality and yield parameters. The maximum plant height was recorded in Laura $(43.53 \mathrm{~cm})$ followed by Delfin $(43.33$ $\mathrm{cm})$ whereas the minimum plant height was recorded in Samuraj $(30.60 \mathrm{~cm})$ followed by Kormoran $(30.80 \mathrm{~cm})$ and Partrizia (32.00 $\mathrm{cm})$. The plant height being genetically factored, it is expected to vary among the cultivars (Sarkar and Ghimiray (2004). Gerbera cultivars showed significant variation for number of leaves per plant. Maximum number of leaves was observed from Partrizia (10.33/ plant) and minimum from Laura and Samuraj (7.20/ plant). This variation may be due to the response of varieties of varying genetic make up to the environmental condition. Similar variations were also reported due to such interactions by Bhuyar and Sable (2003), Kumar and Kumar (2001), Gajanana et al., (2003) in gerbera. Leaf length and width showed significant variation among 
gerbera cultivars. Maximum leaf length and width were found from Szantal $(28.33 \mathrm{~cm}$ and $16.33 \mathrm{~cm}$, respectively). The marked variation in vegetative characters may be due to differential characters of individual varieties that expressed their genetic characters. These results were in conformity of findings of Sarmah et al., (2014).

Table.1 Plant growth of gerbera as influenced by different varieties under

Naturally ventilated polyhouse

\begin{tabular}{lcccc}
\hline Cultivars & Plant Height $(\mathrm{cm})$ & No. of leaves & Length of leaf $(\mathrm{cm})$ & Width of leaf $(\mathrm{cm})$ \\
\hline Laura & 43.53 & 7.20 & 28.00 & 15.00 \\
Szantal & 42.07 & 8.93 & 28.33 & 16.20 \\
Delfin & 43.33 & 8.07 & 29.47 & 14.93 \\
Newada & 37.67 & 7.53 & 21.10 & 12.93 \\
Olympia & 32.27 & 8.53 & 22.27 & 13.27 \\
Kormoran & 30.80 & 9.87 & 21.87 & 11.27 \\
Partrizia & 32.00 & 10.33 & 19.60 & 12.00 \\
Rock & 35.73 & 10.13 & 26.17 & 13.73 \\
Feliks & 32.63 & 9.47 & 24.73 & 10.53 \\
Samuraj & 30.60 & 7.20 & 22.97 & 8.37 \\
CD at 5\% & 3.51 & 1.41 & 2.86 & 1.43 \\
\hline
\end{tabular}

Table.2 Flowering and yield of gerbera as influenced by different varieties under Naturally ventilated polyhouse

\begin{tabular}{lcccc}
\hline Cultivars & $\begin{array}{c}\text { Days to } \\
\text { flowering }\end{array}$ & $\begin{array}{c}\text { Length of } \\
\text { stalk }(\mathrm{cm})\end{array}$ & $\begin{array}{c}\text { Diameter of flower } \\
(\mathrm{cm})\end{array}$ & No. of flowers/ plant \\
\hline Laura & 116.33 & 62.07 & 8.70 & 13.20 \\
Szantal & 118.67 & 61.87 & 10.73 & 14.87 \\
Delfin & 120.00 & 61.87 & 10.50 & 13.67 \\
Newada & 121.33 & 50.40 & 9.23 & 12.73 \\
Olympia & 111.33 & 62.73 & 9.40 & 14.67 \\
Kormoran & 101.67 & 50.07 & 8.80 & 15.20 \\
Partrizia & 103.67 & 80.20 & 10.67 & 16.53 \\
Rock & 106.67 & 60.73 & 8.27 & 15.40 \\
Feliks & 114.33 & 73.20 & 10.22 & 14.00 \\
Samuraj & 119.67 & 58.40 & 10.33 & 11.53 \\
CD at 5\% & 5.93 & 1.91 & 0.79 & 1.29 \\
\hline
\end{tabular}


Fig.1 General view of evaluation of gerbera varieties in naturally ventilated polyhouse

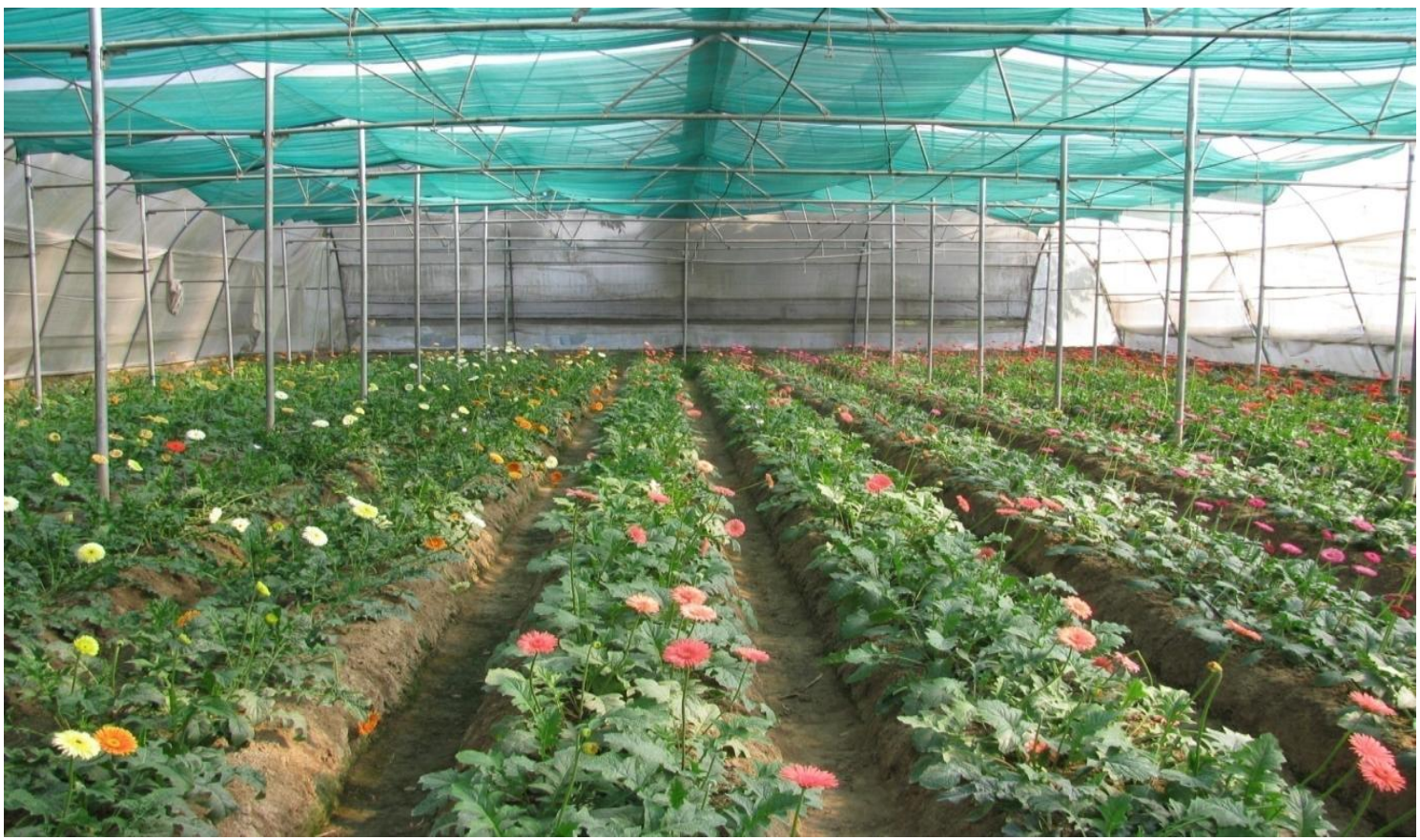

Fig.2 Different varieties of gerbera

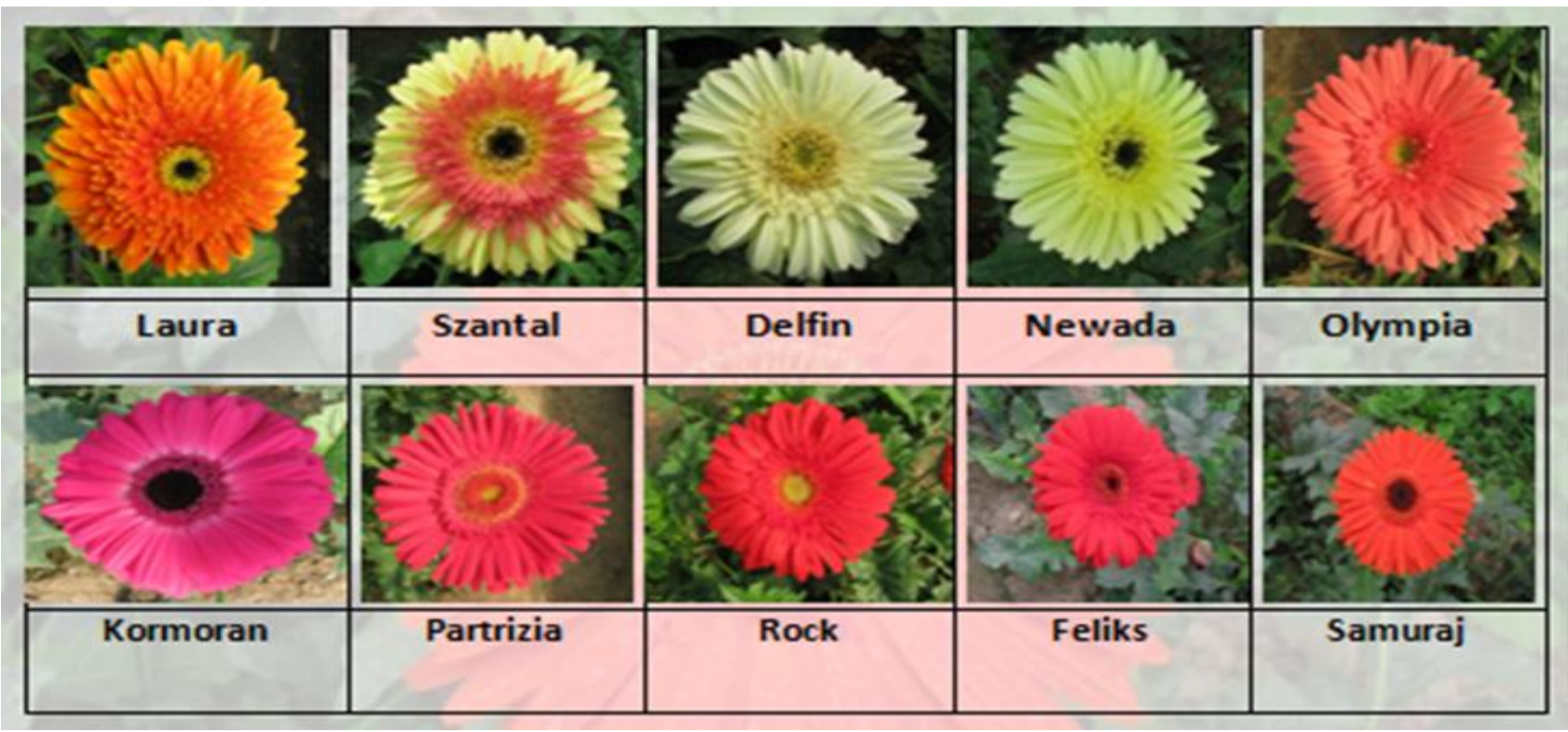

The results of different varieties of gerbera regarding flower characters were found to be significant (Table 2 and Fig. 2). The variety Kormoran required minimum days (101.67) for flowering, whereas variety Newada required maximum days (121.33). The longest stalk of gerbera flower was found from Partrizia $(80.20$ $\mathrm{cm})$ while the shortest was found from Kormoran $(50.07 \mathrm{~cm})$. The stalk length is a genetic factor therefore; it is expected to vary among the cultivars as earlier observed by Sarkar and Ghimaray (2004). Stalk length is a 
very important factor for gerbera cut flower. It decides the quality of cut flowers. As there will be more stalk length more reserved food will be stored in the stalk which will later be available to the flower for longer time period. The findings are in accordance with the result reported by Ahlawat et al., (2012), Chobe et al., (2010), Pareneetha (2006), Naik et al., (2006) and Singh and Ramchandran (2002). Flower diameter showed significant variation among the gerbera cultivars after blooming. Maximum flower diameter was recorded from Szantal $(10.73 \mathrm{~cm})$ while minimum from Rock $(8.27$ $\mathrm{cm})$. The size of these flowers may be due to bigger ray florets which are in conformity with the findings of Sarmah et al., (2014) in gerbera. The bigger diameter of Szantal might be due to the inherent characters of individual varieties.

Significant variation was recorded among gerbera cultivars performance in respect to the number of flowers per plant. Maximum number of flowers were recorded from Partrizia (16.53/ plant) whereas minimum was recorded form Samuraj (11.53/ plant). The above mentioned findings indicated that considering the important characteristics, Partrizia is the best variety having longest stalk length and more number of flowers per plant. While, Szantal and Feliks also exhibited acceptable physical and flowering quality characteristics, so it can also be cultivated under polyhouse.

\section{References}

Ahlawat, T.R., Barad A V and Jat G 2012. Evaluation of gerbera cultivar under naturally ventilated polyhouse. Indian $J$. of Hort., 69 (4): 606-608

Bhuyar, A.R., and Sable A S 2003. Assessment of gerbera cultivars under fan and pad cooling system greenhouse. Symp. Recent
Adv. Indian Floric. Trichur, 12-14th November, Proc. Indian Soc. Orna. Hort.: 134-136

Chobe, R.R., Pachankar P B and Wanade S D 2010. Performance of different cultivars of gerbera under polyhouse condition. The Asian J. of Hort., 2: 333-335

Gajanana, T.M., Singh P K, Subsramanyam K V and Mandhar S C 2003. Economic analysis of gerbera cultivation under protected cultivation. Indian J. Hort., 60(1): 104-107

Kumar, D., and Kumar R 2001. Effect of modified environments on gerbera. $J$. Orna. Hort., 4(1): 33-35

Naik, B.H., Chauhan N, Patil A A, Patil V S and Patil B C 2006. Comparative performance of gerbera cultivars under naturally ventilated polyhouse. J. Orna. Hort., 9(3):204-207

Panse, V.G., and Sukhatme P V 1984. Statistical Methods for Agricultural Workers. Third edition, Indian Council of Agricultural Research, New Delhi.

Paraneetha, S., 2006. Performance of gerbera genotypes at Sheraroy hills of Tamil Nadu. J. Orna. Hort., 9(1):55-57

Sarkar, I., and Ghimiray T S 2004. Performance of gerbera under protected condition in hilly region of West Bengal. J. Orna. Hort., 7(3\&4): 230-234

Sarmah, D., Kolukunde S and Mandal T 2014. Evaluation of gerbera varieties for growth and flowering under polyhouse in the plains of west Bengal. International Journal of Scientific Research, 3(12): 135-136

Singh, K.P., and Ramchandran N 2002. Comparison of greenhouses having naturally ventillation and fan and pad evaporative cooling systems for gerbera producation. J. Orna. Hort., 5(2): 15-19

\section{How to cite this article:}

Paramveer Singh, Ajay Bhardwaj, Randhir Kumar and Deepti Singh. 2017. Evaluation of Gerbera Varieties for Yield and Quality under Protected Environment Conditions in Bihar. Int.J.Curr.Microbiol.App.Sci. 6(9): 112-116. doi: https://doi.org/10.20546/ijcmas.2017.609.013 